\title{
Some Comments on Reports of Post- Secondary Commissions in Relation to Community Colleges in Canada
}

\author{
GORDON CAMPBELL*
}

Historians may well judge the advent of community colleges to be the most dramatic and visionary of the many astonishing developments, during the past fifteen years, in Canadian post-compulsory education. It is especially tantalizing to reflect upon the assessment that historians may make of the relationships spawned between these new colleges and the universities. Universities have shaped the mind and character of an elite; the inception of community colleges marks in our society the beginning of a stage that regards universal access to post-school education as a paramount objective. It is not suprising that these colleges are attracting not only a large measure of public interest but, also, close public scrutiny. ${ }^{1}$ The powerful and often elusive economic, demographic, cultural and political forces that brought them into being, continue to shape their nature. Unlike universities, anchored by centuries of tradition, the colleges reflect to an unusual degree this nation's political pressures, cultural variety, and economic regionalism. Their youth make them particularly pliant.

This paper examines assertions that the four reports ${ }^{2}$ have made about colleges. Special attention is paid to university-college relationships. It is appropriate to offer first, because of the paucity of comparative Canadian studies about colleges, a profile of Canadian college systems. The remarkable diversity and vitality of colleges are readily apparent. Most of this paper will be given to exploration of two issues raised in the reports with which college systems are currently grappling: (1) centralized control; (2) parity of esteem.

The paper assumes, perhaps at the risk of being arbitrary, systems do exist in every province at the tertiary level and that, by and large, they fall into three categories: ${ }^{3}$ unitary, binary, and ternary. These categories help one to appreciate the variation in structure and function of Canadian colleges; to discern the arrangements between colleges and universities; and to formulate precise statements about the purposes and distinctiveness of college systems. The criteria for these categories include purpose, administrative structure, and articulation with universities.

\section{Binary System}

The prototype of the binary system is found in Ontario. There, as in the United Kingdom, post-school education ${ }^{4}$ is separated into two sectors, one comprising the universities and the other, the Colleges of Applied Arts and Technology (CAATs), ${ }^{5}$ each sector developing independently of the other. Unlike colleges in some other provinces, the 
Ontario colleges did not evolve; on the contrary, the Ontario system was designed.specifically, in 1965 , to create a clear alternative to degree-granting institutions. The rationale for the establishment of colleges (some of which had been institutes of technology) was stated by the Grade 13 Study Committee (1964);

We must create a new kind of institution that will provide, in the interests of students for whom a university course is unsuitable, a type of training which universities are not designed to offer. Fortunately, a beginning has been made in the establishment of the institutes of technology and vocational centres ... The Committee is therefore recommending the establishment of community colleges to provide these new and alternative programmes. ${ }^{6}$

There are now twenty-two colleges, with more than sixty campuses, offering 2,000 programs to 55,000 full-time students.

In his statement to the Legislature, introducing the Bill providing for the establishment of "a system" of Colleges of Applied Arts and Technology, Mr. Davis makes clear that he was not advocating a form of junior college with emphasis on university-parallel courses.

Nonetheless no able and qualified student should be prevented from going on from a college of applied arts and technology to a university . . . Moreover, I have no doubt that where circumstances warrant it some of our universities will make arrangements with particular colleges of applied arts and technology, as provided in the proposed legislation, to conduct one or two years of their own degree courses within those colleges. The present university extension courses leading to a general arts degree might be a logical beginning point. ${ }^{7}$

As the Wright Report observes, "When the new institutions emerged after 1966, they were not community colleges of the American type - 'screens' or 'revolving doors' to universities - but genuine alternatives with functions different from those of the universities, open to a wide clientele and closely tied to their communities." 8 Educational issues, aside, undoubtedly it was shrewd political and fiscal strategy to create a clear dichotomy between colleges and universities. Whether this situation ought to continue will be examine further on.

The binary system exists also in each Atlantic province and in Manitoba. Prince Edward Island duplicates the Ontario model; indeed, the letterhead of Holland College, Charlottetown, proclaims that institution as a College of Applied Arts and Technology. New Brunswick recently has formalized a binary system in which the non-university sector, consisting largely of existing institutes of technology, is governed by one provincial board of governors. In Manitoba, a newly elected NDP government changed (1969) to "community colleges" the name of the existing institutions. The change was more decorative than substantive; in function, the institutions remain largely trade schools. In the judgement of the Oliver Commission, they have fulfilled insufficiently their mandate to become a clear alternative to universities. In fact

The community colleges in Manitoba are very much trade or vocational schools. They are not really "community" colleges since they respond only partly to specific local needs. They offer a relatively narrow range of choices and they all rely heavily on the demands made by Canada Manpower in determining what course they will offer and to how many students. ${ }^{9}$

Little action has been taken on the Task Force Report in Manitoba. ${ }^{10}$ 


\section{Ternary System}

As noted, the binary system presents a clear separation between theoretical and academic orientation of the universities and the specialized and vocationally orientated colleges. The ternary system includes three components: universities, community colleges operating under a "Colleges Act" and including a board of governors and a third category consisting of institutes of technology, and other specialized institutions and agencies managed directly be a government department. ${ }^{11}$

Unlike Ontario, where colleges were created with astonishing speed, the Alberta system simply evolved. Curiously, the early days in Alberta resembled the current system in Ontario. The University of Alberta, founded in 1906, catered to degree-granting requirements and sponsored a flourishing province-wide extension operation. The Southern Alberta Institute of Technology, since its inception (1916), has been managed by the Department of Education. It provides vocationally oriented programs including outstanding opportunities in the cultural arts. A comparable range of technical studies is offered by the Northern Institute, founded in 1961. The first community college, established at Lethbridge in 1957, offered both university-level and vocational studies. ${ }^{12}$ As more colleges were added, a Colleges Commission was created in 1969 parallel to existing Universities Commission. Thus, the establishment of a twin-commission system of coordination perpetuated the cleavages between the university, the community colleges, and a variety of other institutions managed directly by the province's Department of Education.

Albertans seemed to prefer, as the Worth Report pointed out, a "combined development model."

Such a model provides for the continued differentiation among and within types of institutions, but evisages new means to improve linkage. This combined structure differs from Alberta's earlier fragmented model that prompted the separate and discordant growth of agricultural schools, colleges, institutes, and universities. This combined development model also differs from the binary model which segregates non-university institutions from universities. ${ }^{13}$

Following the publication of the Worth Report, the government adopted as its goal "the abolition of a non-functional hierarchy of prestige" and the creation of a fully federated system. The Universities Commission and the Colleges Commissions were disbanded; a Department of Advanced Education was created to establish a mechanism whereby the total requirements of post-school education can be met through a system of diverse institutions and agencies. Each part of the system serves some special pupose or a particular area but collectively the system offers an astonishing range of educational choices. ${ }^{14}$ The most significant components are four universities, six community colleges, the Banff Centre, two institutes of technology, three agricultural colleges, twenty-five vocational training centres and sixty further education councils. The principal function of the new Department is to ensure "federation through coordination" and to provide broad guidelines for the planning of individual institutions.

In Saskatchewan, the community college unit of the ternary system resembles none other in Canada. ${ }^{15}$ High priority is given, not to buildings and campuses but, rather, to extending through community organization the services of the universities, institutes of technology, the provincial library and other government agencies. Saskatchewan is cre- 
ating a new structure that emphasizes learning arrangements, rather than a physical plant; the structure is concerned more with its relation to other agencies than with the colleges as an institution per se. As in Alberta, the government created a new department to administer the ternary system. It is called, significantly, the Department of Continuing Education. An educational communications network (video, audio, film, print) is being incorporated within the college system to permit maximal accessibility to learning programs in a province with a substantial rural population. ${ }^{16}$

The ternary system in British Columbia resembles that of Alberta, in relation to its evolving character and three-fold division. ${ }^{17}$ It is distinct in Canada, however, in the close alliance that colleges have with school-district boards. ${ }^{18}$ British Columbia has been influenced, to a remarkable degree, by American experience. A second characteristic, now unique in Canada, is the requirement of local taxation in school districts supporting colleges. ${ }^{19}$ Whereas in Alberta, the Universities Commission was abolished, a comparable body called the Universities Council has been established recently in British Columbia. That province's ternary system is unlike Alberta's in two further respects: the British Columbia Institute of Technology has been incorporated under its own legislation providing for a board of directors, ${ }^{20}$ and one Department of Education administers every level of education in the province. A major step has been taken this year in making university degree programs available throughout B.C. Simon Fraser University and Okanagan College have joined forces to offer degree-completion programs in two fields. The courses will be taught in Kelowna by Simon Fraser faculty; thus, a Simon Fraser degree can be earned without students ever attending the Simon Fraser University campus. A comparable cooperative arrangement is being planned by the University of Victoria and Malaspina College in Nanaimo.

\section{Unitary System}

The unitary system is confined to Quebec. There, the community colleges (Collèges d'enseignement général et professionnel - CEGEP) are the third level in a four-tiered provincial system of education. Only in Quebec must students seeking to enter university enrol, first, in a college. This requirement separates Quebec from all other provinces although there are many distinguishing features of the college-university system. In other respects, there are common characteristics. Both the CAAT system and the CEGEP system were perceived by their respective governments as innovations, and each was initiated by a single act of legislation. Both systems were operational within a year, both incorporated pre-existing institutions from a mélange of relatively undefined educational levels; and both grew out of preliminary studies that were followed by nearly unanimous agreement as to need and character. ${ }^{21}$ Quebec's colleges, unlike Ontario (but similar to Alberta's) prepare students either for transfer to university or for employment. A requirement that the first phase of university studies be undertaken within colleges binds the latter to universities to a degree unmatched in Canada. This fact, added to the high degree of central-government control (as in Ontario) leaves Quebec colleges substantially less autonomous than those in western Canada.

The CEGEP system differs also from other provinces in the nature of the relationship to larger educational structures. Quebec colleges are an outcome of the general reformulation of the entire educational enterprise that followed the Parent Report. No such 
upheaval took place in the educational alignments of Ontario. There the college system was introduced as a separate entity into previously existing structures without extensively modifying prevailing arrangements.

It would violate the facts to advance too far the above three-fold categorization. In Quebec, for instance, interinstitutional differentiation is considerable. Striking contrasts exist, for instance, between anglophone and francophone colleges. Moreover, Quebec's transition from a largely rural and traditional culture, to the ways of the city and a man-made ambience, has kaleidoscopic dimensions not easily classifiable; in other words, changes in structure are still taking place and categorizations must be tentative.

The most fundamental recommendation of a structural order made by each of the reports is that post-school education be regarded as one integrated system of further learning. Clearly this approach is viable only if the uniqueness of each component is protected. While a number of characteristics of community colleges differentiate them from universities, the overriding distinction revolves around the task of providing job training programs both for the conventionally aged students and for older and/or disadvantaged individuals. The central fact about the job-training aspect of community college courses is that they are generally designed to fit the need for training/education

as perceived by government rather than by the institution itself or the public at large. ${ }^{22}$ This being so, it is unfortunate that the governments of Manitoba, Ontario and Nova Scotia have not brought into being more of the recommendations of their Task Forces which would allow colleges to carry out more expeditiously the objectives they were designed to serve.

\section{Inaction Upon the Reports' Recommendations}

It may be useful to employ the Wright Report as an illustration of how few of the proposals in the four reports (with the possible exception of Alberta) have been carried into action. ${ }^{23}$ Obviously, it will be possible here to refer to only a few of the recommendations. One stance taken by the Ontario Government concerns the apparent deliberate avoidance in building additional alternative structures in the post-secondary field. No formal move has been made, for instance, to create a new structure in the form of an Open Academy. However, funds awarded to such non-institutional learning as libraries and museums has improved since the Wright Report, and this at a time when institutional funds have been under an inflationary squeeze. What may be significant here is the apparent desire of the Provincial Government to make sure that "educators" would not get hold of the Open Academy and perhaps turn it into another rigid institution. (About six months ago, the government created a new Ministry of Culture and Recreation and took all cultural and "open sector" activities away from the Ministry of Colleges and Universities. The main activity of the new ministry to date has been the establishment of an Ontario government lottery). In this connection the comments of W. Worth are relevant.

Members of bureaucracies engage in nest-feathering and self protection. Officials come to have a vested interest in their organization's survival. They thus consolidate their power. And over time the temptation grows for them to use the organization for their own ends; to the neglect of the interests of its constituents and clientele. Within higher education, this trend toward privilege helps 
explain why institutions do not welcome competition from rival organizations or requests for information about their activities from external agencies or groups; why universities and sometimes colleges tend toward serving their highest status clientele - leaving to other educational institutions the job of aiding the "unrespectable"; why faculty associations devote so much more energy to professorial/ instructor rights than to professorial/instructor responsibilities; and why some faculty members claim that they alone have the right to make decisions not only about the means to their institution's ends but about the ends themselves. ${ }^{24}$

The goal of equality of access insofar as it is economically possible is recognized by the Government. However, the Wright proposals for achieving this have not been implemented. The Government is studying the proposed increase in tuition fees along with improved student assistance. Still there is a political problem involving the strong lobby to reduce tuition fees. The chairmen of the Council on University Affairs and the Council of Regents for CAATs are co-chairmen of a task force to prepare a new master plan for Student Assistance by fall 1976. It will be necessary to get such a system well established and understood before tuition fees can be increased significantly, even though taxpayer pressure to increase fees is mounting.

There have been some changes to permit experimentation with governing bodies. But with increased faculty militancy in the colleges it has been necessary for government to protect the autonomy of local boards of governors by centralizing collective bargaining and continuing to exclude faculty in particular from boards of governors. In view of the apparent desire of faculty unions, as seen by the Government, to price themselves out of a job through unrealistic salary and workload demands, the original intentions to put more local autonomy in the hands of boards of governors has been postponed. (One hopes that it will not be necessary to turn the colleges back into provincial technical institutes, but this possibility cannot be ruled out under the present climate of public opinion).

The Wright Commission made a series of recommendations concerning professional standards and programs. (Recommendations 53 to 65). There is no indication of any proposed legislation concerning them. Indeed, Ontario policy on the rights of selfregulatory professions is based on the McRuer Report and not the Wright Report. The Wright Report recommendations regarding teacher training (Recommendations 66 to 76) have been ignored. The Wright Recommendation that an Ontario Human Development Commission (Recommendations 85 and 86) be established has not been acted upon. Proposals of the Wright Report that faculty and institutions should create and maintain provincial associations (Recommendations 97 and 98) have not developed although the need is overwhelmingly obvious. As the Government sees it, there are enough problems with faculty unions and student associations without encouragement to organize further.

While the Government of Ontario, then, has not appeared to act upon many of the specific recommendations, the Report has clearly been an enormous influence. The process of insuring a discussion by means of a Preliminary Statement of Issues, an interim report and then a final report has been invaluable. These documents, the briefs and hearings created attitudes directly influencing educators, lawmakers, the public and therefore the evolution of post-secondary education in Ontario. 


\section{Worth Report}

It is no easy task to assess the magnitude of the changes in non-degree, post-secondary education in Alberta following the publication of the Worth Report and the appointment of Dr. Worth as Deputy Minister of the new Department of Advanced Education. Unlike the Wright Report where the recommendations were explicit, the proposals for change by the Worth Report are scattered through the text of the entire unindexed volume. Suffice it is to say that scarcely any element of the delivery system to the part-time and full-time student - rural and urban - has not been modified or reshaped by the philosophy of the Report and the subsequent policies of the Department.

Perhaps the most important change is the determination to bring about a coordination of services, administratively and educationally, at a variety of levels across the province, both within institutions and adult educational agencies while not diminishing the diversity of choices available to students. Top priority has been given to rationalizing the roles, mandates and growth patterns of all colleges. Basic to this process has been the insistence that comprehensiveness resides not within one set of institutions but within the total system including non-institutional delivery systems. One illustration of how coordination and comprehensiveness is being pursued can be seen in the creation of the Council on Articulation and Transfer. The Council consists of a full-time independent chairman, four representatives from the universities and four from the non-university sector. The delicate task of the Council is to accept and act on delegated authority, previously residing exclusively in colleges and universities, concerning the transfer of student between institutions on the basis of credit.

In addition to rationalizing the roles of colleges and the determination to provide a comprehensive province-wide system, (aided, incidentally, by the recent addition of Manpower to the Department of Advanced Education) is the policy analysis approach to the achievement of quality. Alberta's evolving system mushroomed during the sixties as it had everywhere else. With the publication of the Worth Report and the levelling of growth patterns, there is a determination to infuse quality into the educational performance in every compartment of the structure. There is no question that Alberta's affluent circumstances makes this goal in all its complexity substantially easier to achieve in Alberta than in less favored provinces. By no means have all of the proposed changes by the Worth Commission come into being nor have the changes now adopted been everywhere joyfully accepted. A review of all legislation affecting post-secondary learning in Alberta is underway. Again, the alteration in things implicit in fresh legislation provides academic Alberta with something of a lull before the impending storm.

\section{Government Control}

The proper balance in decision-making between provincial and local authorities is a central issue being wrestled with by all the college systems. Who makes the policy? What are the goals? Who is to be served? By what means? As the Wright Report phrases it

How can we, "accept" the need for public accounting of the monies spent on education (yet) devise ways of keeping this sound principle from slipping into political intervention or uniform controls that would threaten to stifle, if not to snuff out, the centres of quality and fresh creativity that only a diverse and flexible system of post-secondary education can provide? ${ }^{25}$ 
Colleges argue that in order to fulfil their mandate to be resilient, imaginative and nontraditional, they need increasing autonomy. Governments see other sides of the cube. According to them, an institution with too much autonomy gets aspirations of upward mobility (the university) to the neglect of the new constituencies colleges were created to serve. Moreover, the outstanding reputations achieved by institutes of technology in Western Canada managed from their inception by departments of education, destroys the argument that governments by definition stultify, and mismanage educational institutions.

Colleges in Ontario and elsewhere had the promise at their inception of contributing to a flexible, open and variegated system of education. Colleges were not to become homogenized, government managed, look-alike places. The facts suggest, however, that colleges are being drawn ever faster into this perilous state of affairs. Despite promising efforts to decentralize, decision-making power still rests mainly with central bodies. The Wright Report condemns this lack of power within individual colleges to influence major decisions. ${ }^{26}$ The same circumstances apply to an even greater degree in Quebec, in Manitoba and Ontario, all (in Alberta, the majority of) college personnel are civil servants; the absence of individuality and creativity in Manitoba's colleges are described by the Oliver Report:

Rigidity appears to be a key characteristic of all aspects of the community college; the theme running through our recommendations is the need for greater flexibility in all facets of the operation of the colleges. One of the sources of the rigidity found in all the colleges is the extreme centralization of decision making in the Community Colleges Division of the Department of Colleges and Universities Affairs. From all of the colleges and from all constituencies within them we heard complaints about the length of time it takes to introduce a course, to hire staff, to receive supplies, as these activities are centralized in the Division. In addition, the individual institutions cannot allocate student assistance in an equitable way because if comes from a bewildering variety of agencies. ${ }^{27}$

The three western provinces, however, reveal structures that allow for goals of diversity and institutional individuality. The range of educational choice for adults in Alberta is broader than any other province or state in North America. ${ }^{28}$ The Saskatchewan system demands that a college have a large degree of freedom in working out ways to serve the many different rural communities. In Alberta, while government control remains firm in respect to the institutes of technology and agricultural schools, the community colleges, with a student and faculty member and the president on the eight-person board, enjoy considerable freedom from central authority. (Only a minority of the non-degree faculty students in Alberta attend community colleges; most are enrolled in the government managed technical institutes. Further, the two newest colleges in northern Alberta are, like the institutes of technology, to be government managed). Local taxation for colleges and the close connection of colleges in British Columbia with the school board has undoubtedly increased the degree of local control in that province.

Elsewhere in Canada, the non-university sector is under much tighter government control than universities. Two clear, but contradictory, trends emerge in considering the tug and pull of autonomy versus control. One trend, more rhetorical it seems, than real, is found in pressures generated by college boards and faculty for increasing autonomy. 
In order to fulfil their basic functions, they argue for more independence in programming. It is precisely in this area that institutions left to their own devices would provide an uneven service throughout the province. As Worth states

In such an interconnected and interdependent system of institutions, programs and services, the offerings of individual institutions can no longer be left to chance. Large-scale planning is necessary to coordinate the many parts of the system, and since this is obviously beyond the capacity of any single college or university, agencies for this purpose have emerged as the newest feature on the academic landscape throughout the Western world. ${ }^{29}$

At another level, the second trend toward greater government control with diminished local initiatives has actually occurred. The Worth Report recommended the abolition of the highly respected Colleges Commission. ${ }^{30}$ It argued that a Department of Advanced Education, centralized coordination would permit a more equitable distribution of college services within the province. In Alberta, there are few colleges today that would not prefer a return to the college commission system precisely because that system enhanced local control and the distinctiveness of colleges.

The issue, of course, is not autonomy versus central direction. Rather, it is to discover the appropriate balance in the equitable allocation of funds and the need for institutional flexibility without bureaucratic meddling and political intervention so that societal goals can be achieved efficiently and economically. Left to their own devices, institutions (in the west especially) have tended to permit community and faculty forces to move a college toward the university model, and thus neglect essential continuing education responsibilities. A prodding Colleges Commission transformed Alberta's colleges from being feeder stations to a university into serving a variety of publics. Still, under the banner of coordination, the threat remains that colleges are being so tightly controlled that their initial refreshing individuality is sometimes close to suffocation.

What the various reports have not faced up to is the possible redundancy of boards of governors, as presently operating. Instead of serving as "buffers" to direct government control, some boards with their political appointees have frequently aided it. Instead of being representative of the college community, some boards have become immune to the real forces operating within and external to the institutions. Instead of being protective at the policy level of powers enabling imaginative community programming, some boards have become a bulwark of safe conduct for institutional bureaucracies. As the Wright Report observes, the creation of boards with advisory committees has become a legal fiction that has obscured growing governmental control. ${ }^{31}$ As indicated above, institutes of technology have for years across Canada served a more restricted clientele in one sense, but secured it more responsibly and imaginatively than some colleges equipped with a board of governors. One function of the board is to anchor the college in the community. With this well done the issue is then not so much one of the paraphernalia of government as it is one of finding leadership with courage enough to fight encrustation and boredom at whatever level, and serve the people where they are, on their terms, and thus make the college accountable.

A college may be self-governing and possibly self-renewing but it is self-deceiving if it denies that it owes its existence to society, with ultimate accountability to some representation of interests broader than the strictly academic. ${ }^{32}$ 


\section{Parity of Esteem}

Colleges are still in the process of finding a place in the existing structure of postcompulsory education. Their search is obstructed by the almost universal practice of measuring the worth of each college in the terms applied to that most prestigious, powerful, and entrenched institution at the tertiary level, the university. Particularly for people inside the university, the hierarchy of things seems fixed; few doubt that the tradition of research, training in the professions, and teaching in the pure and abstract disciplines places the university at the apex of an educational pyramid. Practical studies, especially those associated with the acquisition of manual skills may lead to some sort of diploma, but seldom a degree.

Society has begun to see things differently. A value scale that would confine higher education exclusively to universities and imply that all else is "lower", is scarcely acceptable in a contemporary approach to mass higher education. Happily, substantial institutional diversification is taking place. Learning centres will tend to be regarded as either "higher" or "lower", in relation to how well they realize their respective and different objectives. "We suspect that the real problem," asserts the Wright Report, "lies neither in the imposition of an artificial uniformity on the whole of the post-secondary education, nor in any decreed comparability of academic quality. What is needed is parity of esteem." 33 Easily said; the ideal, of course, is to create an arrangement among institutions through which both full-time and part-time students may move and return in a fashion rendering meaningless the attribution of "more noble" and "less noble" to $a$ whole category of institutions.

But how is this ideal to be achieved? There is evidence to suggest that the binary arrangement in Ontario may not be moving in a desirable direction. Anisef's study of Grade 12 students' future plans, conducted in 1973, observed that

students who plan on enrolling in universities differ markedly from all other groups of students. They tend to be male, rank high on social class background, come from urban areas in Ontario, believe they have the ability to graduate from university (and have the grades to back up this claim) and possess higher occupational aspirations than students with other types of intentions. Thus students who plan on entering a CAAT contrast sharply . . Proportionately more tend to be female; they come from less prestigious backgrounds and possess fewer illusions concerning their ability to graduate from university or obtain very prestigious jobs. Their grade point averages also tend to be lower than than of university bound students. ${ }^{34}$

In contrast to Quebec colleges, where university students must first enrol in a community college, or in Alberta and British Columbia where a student may opt to obtain two years of university standing at a college, a mere trickle of students transfer from the CAATs to universities. And so arises a critical question for Ontario: instead of having two solitudes; is it desirable and is it possible to organize the tertiary level of education as a process that is flexible and reversible rather than irreversible and mutually exclusive? Could such a system establish admission to its different parts by criteria more objective than educational background and social origin? Given the social and indeed the global realities to which higher education must respond, are Canadian citizens best served by separate university and non-university systems? Dorotea Furth speculates upon one possible line of development in such an arrangement. 
While separate development may contribute to reinforcing even more the dichotomic nature of the system by widening the gap between "noble" and "less noble" institutions, it may also contribute to the development of such a large and widely diversified system offering all types, levels and patterns of study that, sooner or later, the traditional university sector would represent only a minority in the overall system and gradually lose its dominant position; "integration among equals" could then be envisaged as a realistic possibility. ${ }^{35}$

The binary model clearly allows colleges freedom to work independently from certain rigidities often so characteristic of universities. Of course there is no suggestion that the separate development of colleges and universities should cease or that colleges should become integrated more closely with universities. (While such a step might effect needed reformation of university methods and goals, it might lead to a stagnating uniformity of the entire post-school sector and not to widely diversified levels and patterns of study). In any event, the current situation in Ontario is not universally satisfying. As a dissenting opinion in The Select Committee on the Utilization of Educational Facilities Final Report observes:

The original statement about the community colleges pointed to a college system in which there would be no walls between these colleges and the communities in which they are located. Unfortunately, the potential foreseen for the colleges has not been realized. The community colleges have become entrenched bureaucracies which have failed to carry out their mandate. ${ }^{36}$

One Wright Report recommendation (opposed almost universally by college faculty, presidents and students in Ontario $)^{37}$ that colleges should grant distinctive bachelor's degrees provided, of course, that they continue to offer general and technical non-degree studies, needs more exploration from the long range societal point of view. Our society has an obsession with degrees; they represent a yardstick of achievement. (Many diploma graduates from Ryerson Polytechnical Institute are returning "to upgrade their diploma to degree status"). Since such tangible symbols appear to be a measurement of learning in our culture, they perhaps ought to be widely available to suit the present technical training requirements of society. This is not to argue that Canadian colleges should adopt the American Associate of Arts degree, or that they should become junior colleges whose credits can be applied towards a university degree, or that college degrees should be somehow substandard in quality in contrast to degrees awarded by universities. Nonuniversity degrees should be neither identical nor equal to a university degree. What they should be, however, is different, and possess a standard of excellence comparable, say, to the degree administered (with the approval of universities) by the Council for National Academic Awards in the United Kingdom. Until some state authority other than universities, grants degrees for which colleges and other agencies such as the Open Academy might prepare students, parity of esteem between a wide diversity of post-school institutions will not be possible. Thus the cleavage between "noble" and "less noble" institutions will remain; institutions will continue to enroll students along class lines and colleges will perpetuate social class realities and current distribution of income.

There is an ironic twist to the fact that the Ontario Government apparently subscribes to the "parity of esteem" notion as between universities and colleges. Unfortunately it often works to the disadvantage of colleges. The problem concerns financing. If "what is good for the universities is also good for the colleges," CAAT funding has to be a 
variation of the university operating grant formula. Because universities did not receive funding for general interest extension courses for instance, funding for such programs was restricted. As one Ministry official put it, "It has taken two years to convince the university oriented people in our ministry that "parity of esteem" does not mean that colleges have to be carbon copies of universities." 38

\section{Footnotes}

1. In British Columbia, for example, the Government initiated a Task Force on Community Colleges which held nearly one hundred public hearings in 1973-74. This was followed by a special enquiry in to colleges serving the lower mainland area. Within the last few weeks an inquiry has been ordered by the Provincial Government into the operation of Vancouver City College.

2. The Four Reports are: The Learning Society, Report of the Commission on Post-Secondary Education in Ontario, Toronto: Ministry of Government Services, 1972 (otherwise known as the Wright Report); Report of the Nova Scotia Royal Commission on Education, Public Services and ProvincialMunicipal Relations, Halifax: Queen's Printer, 1974 (otherwise known as the Graham Report); Report of the Task Force on Post-Secondary Education in Manitoba, no date, (otherwise known as the Oliver Report) and A Choice of Futures, Report of the Commission on Educational Planning, Edmonton; 1972, (otherwise known as the Worth Report).

3. In Short Cycle Higher Education: A Search For Identity (Organization for Economic Co-operation and Development, Paris, 1973), Dorothea Furth makes a comparable synoptic classification of existing systems of Short Cycle Education (which includes community colleges) around the world. This book is an invaluable reference for students of post-school, non-university systems of education in North America and Europe.

4. The terms "post-school," "post-compulsory" and "post-secondary" are synonymous for purposes of this paper.

5. For purposes of this classification, Ryerson Polytechnical Institute, a degree-granting institution is included with universities (it was granted a new charter in 1971). Other institutions, such as the College of Agricultural Technology and a number of professional schools are classified as colleges. The term "community college" is not to be confused with the term college designating a unit of the university. Included in the non-university sectors are a number of professional schools and four colleges of agricultural technology.

6. Report of the Grade 13 Study Committee, 1964, submitted to The Hon. Wm. G. Davis, Minister of Education, June 26, 1964.

7. Statement by the Hon. Wm. G. Davis, Minister of Education, in the Legislature, May 21, 1965.

8. The Wright Report, p. 12.

9. The Oliver Report, pp. 39-40.

10. A Working Group has been established to recommend on the report. While its studies have not concluded, the situation is as follows:

"1. It has been decided not to establish the Post-Secondary Commission with the three major branches. The Universities Grants Commission will continue in its existing role.

2. The Community Colleges will continue to operate directly out of the Department of Colleges and Universities Affairs. Advisory Boards will be re-established perhaps with more authority than formerly. It is hoped that there can be an increased delegation of authority to the colleges and to the boards.

3. The Task Force recommended a Regional organization to deliver continuing or post-secondary programs of all kinds. A pilot project in a rural area of the province has been established to 
try out this procedure. It is being financed by a grant of $\$ 5$ per capita with a district commission and a regional committee to oversee and develop the operation. The colleges are involved in this in relation to their off-campus courses other than Canada Manpower courses which are not part of the system.

4. The colleges are enthusiastic about more autonomy and would like to be as independent as the universities. They are not happy with the decision not to spin them off.

5. It has not been possible as yet to persuade the government to fund an adequate leave for study program.

6. There is little agreement with the recommendation to phase out Canada Manpower courses from the colleges. This would be a backward step from many points of view."

Personal correspondence with Deputy Minister, Colleges and Universities Affairs, April 22, 1975.

11. Two new community colleges are about to be created in Alberta's northern areas. Significantly, both of these colleges are to be managed directly by the Department of Advanced Education without boards of governors as are institutes of technology and agricultural colleges.

12. The Lethbridge Community College ceased offering the first two years of university studies following the founding of The University of Lethbridge in 1967. The creation of the University represented a precedent of a sort. Other Alberta communities having a college also thought of the possibility of its college evolving into a university. The diverting of this ambition became a prime task of the College Commission.

13. The Worth Report, p. 82.

14. For an excellent analysis of some problems associated with the combination of such a "fully federated system" see "From Autonomy to Systems: A Provincial Perspective," a paper prepared by Walter Worth and presented as part of the 1974 University of Lethbridge Summer Series on Politics of Higher Education, February 21, 1974.

15. See Report of the Minister's Advisory Committee on Community Colleges, Regina: Department of Continuing Education, August, 1972,70 pp.

16. See Faris, Ron, The Saskmedia Report, Regina: Department of Continuing Education, June, 1973, $52 \mathrm{pp}$.

17. See Towards the Learning Community, a working paper on the community college in British Columbia prepared by the Task Force on the Community College, Victoria: The Department of Education, March, 1974, $44 \mathrm{pp}$. See also the final report of the Task Force.

18. New community colleges for the East Kootenays and Northern Vancouver Island have been established by orders-in-council upon request of the school districts concerned. The creation of the new colleges is the result of the Task Force on Community Colleges which recommended that the Department of Education's first priority in post-secondary educational development be the provision of college services in all areas of the province.

19. A plebiscite requirement has been deleted by order-in-council from the Regulations of B.C's Public Schools Act so that school boards may now establish community colleges by passing by-laws; they need no longer seek approval from the electorate.

20. See Report of the BCIT Advisory Council to the Commission on Post-Secondary Education, July $1973,33 \mathrm{pp}$.

21. Nearly all of the CAAT colleges were created in 1906-67. Several additions or perhaps rearrangements have been made since that time. The CEGEP were inaugurated in 1967-68. Many had previously been College Classiques and had the name changed on the door but little else. As the system grew, reformation of existing institutions continued apace, new institutions were added and new administrative echelons of government were created.

22. See Submission to Health, Education and Social Policy Subcommittee From the Working Group or Post-Secondary Education, Government of Manitoba. p. 2., no date. 


\section{Gordon Campbell}

23. The present writer expresses his gratitude to the Minister and officials in the Ministry of Colleges and Universities for their care in providing substantial documentation upon which those views are based. The interpretations, of course, are the responsibility of the present writer alone.

24. W. Worth "From Autonomy to System: A Provincial Perspective," February 21, 1974. p. 7.

25. The Wright Report, p. 103

26. The Wright Report, p. 104

27. The Oliver Report, p. 42

28. Worth, 1974, p. 4

29. Worth, 1974, p. 4

30. The Worth Report, p. 131

31. The Wright Report, p. 103

32. Worth, 1974, p. 18

33. The Wright Report, p. 50

34. Paul Anisef, The Critical Juncture, Educational and Vocational Intentions of Grade 12 Students in Ontario, (preliminary study), Ministry of Colleges and Universities, 1973.

35. Dorotea Furth, "Short-Cycle Higher Education: Some Basic Considerations" in Short Cycle Higher Education, Paris: Organization for Economic Co-operation and Development, Paris, 1973, p. 39.

36. "What happens next is up to you." Final Report of The Select Committee on the Utilization of Educational Facilities, February, 1975. Charles E. McIlveen, M.P.P. Chairman.

37. There was considerable negative reaction to the recommendation that CAATs grant degrees. Most of the reaction came from students. At a time when the pass arts degree was falling into public disfavor (1972) because these university grads couldn't get jobs, CAAT students did not want to be viewed as having attended a "poor man's university." It was felt that a degree would harm their employment opportunity that now exists with distinctive CAAT diplomas. Hence, there is no indication that CAATS will become degree granting institutions in the near future, if ever.

38. Personal Communication, May, 1975. 